\title{
NOTIFIKASI HUKUM KONSTITUSI MELALUI PENDIDIKAN
}

\author{
Astim Riyanto ${ }^{1}$
}

\section{Abstract}

In fulfil law fiction principle "all of man to be of the opinion know law" and legal principle "regulations that already made must be announced", so all regulations must be promulgated/announced. That is did for insurance legal exactly of existence a regulation. With promulgation/announcement a regulation have binded force. This is related with legal promulgation theory. Further, for support the law fiction principle and the legal principle, law understanding spread, and law effectiveness; then can did notification understanding of regulations. This is related with legal notification theory. Notification understanding of The Law of the Constitution can by education, by means of formal education, non formal education, and informal education.

Kata kunci: notifikasi, hukum konstitusi, pendidikan

\section{Pendahuluan}

Hukum Konstitusi dapat dipandang dari dua segi, yaitu segi keilmuannya dan segi aturannya. Hukum Konstitusi, sebagai ilmu, adalah Hukum cabang atau spesialisasi Hukum Tata Negara yang mempelajari konstitusi sebagai obyek material dan hukum dasar sebagai obyek formal termasuk Undang-Undang Dasar sebagai Hukum Dasar tertulis yang menjadi dasar hukum tertulis tertinggi dari tata hukum nasional. Hukum Konstitusi, sebagai aturan, adalah seperangkat aturan dasar atau Hukum Dasar yang dibuat oleh yang berwenang yang menetapkan dan mengatur organisasi negara dari suatu negara.

1 Penulis adalah Doktor Hukum Tata Negara spesialisasi Hukum Konstitusi, Magister Hukum Tata Negara spesialisasi Hukum Konstitusi, Sarjana Hukum Pidana, Sarjana Pendidikan Kewarganegaraan dan Hukum, Dosen Teori dan Hukum Konstitusi, dan Kepala Divisi Hukum Universitas Pendidikan Indonesia (UPI). Bukunya antara lain Teori Konstitusi (1993, 2000, 2006), Kapita Selekta Hukum Dalam Dinamika (2000), Filsafat Hukum (2003, 2007), Teori Negara Kesatuan (2006), serta Negara Kesatuan Konsep, Asas, dan Aktualisasinya (2006). 


\section{Aspek-aspek Dalam Rumusan Hukum Konstitusi}

Dari rumusan Hukum Konstitusi tersebut di atas, lebih lanjut dapat dijelaskan mengenai Hukum, Hukum Tata Negara, dan Hukum Konstitusi.

\section{A. Hukum}

Dari segi keilmuan, Hukum adalah ilmu yang mempelajari norma dan peraturan. Dari segi aturan, Hukum adalah seperangkat aturan yang dibuat oleh yang berwenang secara tertulis atau tidak tertulis yang bersifat memaksa dan atau mengatur untuk ditaati oleh pihak yang bersangkutan guna mewujudkan kesejahteraan. ${ }^{2}$

\section{B. Hukum Tata Negara}

Dari segi keilmuan, Hukum Tata Negara adalah Hukum yang mempelajari organisasi negara dari suatu negara. Dari segi aturan, Hukum Tata Negara adalah seperangkat aturan yang dibuat oleh yang berwenang yang menetapkan dan mengatur organisasi negara dari suatu negara.

\section{Hukum Konstitusi}

Dari segi keilmuan, secara singkat dapat dirumuskan Hukum Konstitusi adalah Hukum yang mempelajari konstitusi (ditulis dengan huruf k kecil). Dari segi aturan, secara singkat dapat dirumuskan Hukum Konstitusi adalah Hukum Dasar yang menetapkan dan mengatur organisasi negara dari suatu negara. Hukum Konstitusi mencakup Hukum Konstitusi dalam arti luas dan Hukum Konstitusi dalam arti sempit. Hukum Konstitusi dalam arti luas adalah Hukum Dasar, baik Hukum Dasar tertulis maupun Hukum Dasar tidak tertulis. Hukum Konstitusi dalam arti sempit adalah Hukum Hukum Dasar tertulis atau Undang-Undang Dasar atau Konstitusi (ditulis dengan huruf $\mathrm{K}$ besar).

Dari rumusan Hukum Konstitusi tersebut di atas, lebih lanjut dapat pula dijelaskan mengenai Konstitusi, Hukum Dasar, dan Undang-Undang Dasar, yaitu:

${ }^{2}$ Lihat Astim Riyanto, "Filsafat Hukum", Cetakan Pertama, (Yapemdo: Bandung, 


\section{A. Konstitusi}

Konstitusi dalam arti luas, yang berarti konstitusi (ditulis dengan huruf $\mathrm{k}$ kecil) selain dipelajari atau dikaji oleh ilmu Hukum c.q. Hukum Tata Negara i.c. Hukum Konstitusi, tetapi juga dipelajari atau dikaji oleh sejumlah ilmu lain, yaitu ilmu politik, ilmu masyarakat (sosiologi) i.c. sosiologi hukum, dan ilmu lainnya. Konstitusi dalam arti tengah, yang berarti Hukum Dasar dipelajari atau dikaji oleh ilmu Hukum i.c. Hukum Konstitusi. Konstitusi dalam arti sempit, yang berarti Undang-Undang Dasar atau Konstitusi (ditulis dengan huruf K besar) dipelajari atau dikaji oleh ilmu Hukum i.c. Hukum Konstitusi.

\section{B. Hukum Dasar}

Hukum Dasar adalah aturan-aturan dasar dalam penyelenggaraan negara. Hukum Dasar mencakup Hukum Dasar dalam arti luas dan Hukum Dasar dalam arti sempit. Hukum Dasar dalam arti luas mencakup Hukum Dasar tertulis dan Hukum Dasar tidak tertulis. Hukum Dasar tertulis adalah aturan-aturan dasar tertulis dalam penyelenggaraan negara. Hukum Dasar tertulis mencakup Hukum Dasar tertulis dalam arti luas dan Hukum Dasar tertulis dalam arti sempit. Aturan-aturan dasar tertulis sebagai aturan-aturan dasar tertulis dalam penyelenggaraan negara dalam bentuk hukumnya berupa peraturan perundang-undangan konstitutif atau peraturan-peraturan legal konstitutif. Hukum Dasar tertulis dalam bentuk hukumnya berupa peraturan perundang-undangan peraturan konstitutif atau peraturan-peraturan legal konstitutif dalam arti luas meliputi UndangUndang Dasar, Undang-Undang ber-muatan konstitusi, UndangUndang organik, Undang-Undang non organik, Peraturan Pemerintah Pengganti Undang-undang (Perpu), Peraturan Pemerintah, Peraturan Presiden, Peraturan Menteri, Peraturan Daerah, Peraturan Kepala Daerah, peraturan pelaksanaan, dan peraturan kebijakan terutama dalam lapangan ketatanegaraan. Termasuk ke dalam Hukum Dasar tertulis, yaitu peraturan khusus, peraturan putusan pengadilan/hakim, dan peraturan traktat terutama dalam lapangan ketatanegaraan.

Hukum Dasar tidak tertulis adalah aturan-aturan dasar tidak tertulis dalam penyelenggaraan negara atau "aturan-aturan dasar yang timbul dan terpelihara dalam praktik penyelenggaraan negara 
meskipun tidak ditulis". ${ }^{3}$ Aturan-aturan dasar tidak tertulis sebagai aturan-aturan dasar tidak tertulis dalam penyelenggaraan negara dalam bentuk hukumnya berupa peraturan-peraturan non legal/ekstra legal konstitutif. Hukum Dasar tidak tertulis dalam bentuk hukumnya

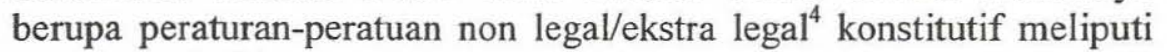
peraturan kebiasaan (usages), peraturan kesepahaman/kesepakatan (understandings), peraturan adat istiadat (customs), dan peraturan konvensi (conventions) terutama dalam lapangan ketatanegaraan. ${ }^{5}$ Hukum Dasar tertulis dalam arti sempit, yaitu Undang-Undang Dasar atau Konstitusi (ditulis dengan huruf $\mathrm{K}$ besar).

\section{Undang-Undang Dasar}

Undang-Undang Dasar (Grondwet) adalah Undang-Undang yang menjadi dasar dari segala Hukum. ${ }^{6}$ Pasal 3 ayat (1) Undang-Undang RI Nomor 10 Tahun 2004 tentang Pembentukan Peraturan Perundangundangan, menentukan:

"Undang-Undang Dasar Negara Republik Indonesia Tahun 1945 merupakan hukum dasar (hukum dasar tertulis, penulis) dalam Peraturan Perundang-undangan".

${ }^{3}$ Penjelasan Undang-Undang Dasar Negara Republik Indonesia Tahun 1945, Umum, 1. Undang-Undang Dasar sebagaian dari hukum dasar:

${ }^{4}$ Lihat dan hubungkan Kenneth C. Wheare, Modern Constitutions, Third Impression (First Published 1951), Oxford University Press, London, New York, Toronto, 1975, hal. 1, mengkategorikan: "The word "constitution" is commonly used in at least two senses .... First of all it is use to describe the whole system of government of a country, the collection of rules which establish and regulate or govern the government. This rules are partly legal, in the sense that courts of law will recognize and apply them, and partly non legal or extra legal, taking the form of usages, understandings, customs, or conventions which courts do not recognize as law but which are not less effective in regulating the government than the rules of law strictly so called".

${ }^{5}$ Lihat dan hubungkan Walter F.Murphy, James E.Fleming, and Sotirios A.Barber, American Constitutional Interpretation, Second Edition, The Foundation, Inc., New York, 1995, hal. 1, mengatakan: "In its narrowest sense, the term constitution refers to the ways in which a government is organized .... In its broadest sense, as Aristotle came to use the word, a constitution reaches far beyond government and designates a people's way of life".

${ }^{6}$ Lihat R. Wirjono Prodjodikoro, "Asas-asas Hukum Tata Negara Di Indonesia", Cetakan Ketiga (Cetakan Pertama 1970), (Jakarta: PT. Dian Rakyat, 1977), hal. 10. 


\section{Teori Promulgasi dan Notifikasi Hukum Konstitusi}

\section{A. Teori Promulgasi Hukum Konstitusi}

Suatu peraturan perundang-undangan secara yuridis formal mempunyai kekuatan hukum sah apabila dibuat oleh lembaga, badan, atau pihak yang berwenang. Apabila ada peraturan perundangundangan yang dibuat bukan oleh lembaga, badan, atau pihak yang berwenang, maka peraturan perundang-undangan tadi tidak mempunyai kekuatan hukum sah atau tidak sah. Suatu peraturan perundang-undangan secara yuridis formal mempunyai kekuatan hukum berlaku apabila dibuat berdasarkan peraturan perundangundangan yang lebih tinggi atau di atasnya. Apabila ada peraturan perundang-undangan yang dibuat bertentangan dengan peraturan perundang-undangan yang lebih tinggi atau di atasnya, maka peraturan perundang-undangan tadi tidak dapat diberlakukan dan dapat dinyatakan batal demi hukum atau tidak berlaku dan batal demi hukum.

Di samping itu, suatu peraturan perundang-undangan secara yuridis formal mempunyai kekuataan hukum mengikat apabila dilakukan pengundangan/pengumuman peraturan perundang-undangan (legal promulgation). Apabila ada peraturan perundang-undangan yang tidak atau belum diundangkan/diumumkan, maka peraturan perundang-undangan tadi tidak atau belum mempunyai kekuatan hukum mengikat atau tidak mengikat. Ini sesuai dengan teori pengundangan/pengumuman peraturan perundang-undangan (legal promulgation ${ }^{7}$ theory) yang menyatakan suatu peraturan perundangundangan secara yuridis formal mempunyai kekuatan hukum mengikat apabila diundangkan/diumumkan. Teori pengundangan/pengumumam peraturan perundang-undangan atau teori promulgasi ini lahir guna memenuhi asas fiksi hukum "semua orang dianggap tahu hukum" dan asas hukum "peraturan-peraturan yang telah dibuat harus diumumkan". Hal itu dilakukan untuk memenuhi atau menjamin kepastian hukum dari keberadaan suatu peraturan perundangundangan. Dengan melalui pengundangan/pengumuman beserta

7 Bandingkan John M. Echols dan Hassan Shadily, Kamus Bahasa InggrisIndonesia, (Jakarta: PT. Gramedia, 1990), hal. 451, mengartikan: promulgate adalah mengumumkan dengan resmi, menyebarluaskan; promulgation adalah pengumuman, penyebaran. 
pendistribusiannya suatu peraturan perundang-undangan mempunyai kekuatan hukum mengikat atau mengikat.

Pasal 1 angka 11 Undang-Undang RI Nomor 10 Tahun 2004, merumuskan:

"Pengundangan adalah penempatan peraturan perundangundangan dalam Lembaran Negara Republik Indonesia, Tambahan Lembaran Negara Republik Indonesia, Berita Negara Republik Indonesia, Lembaran Daerah atau Berita Daerah".

Dalam hubungan dengan pengundangan Undang-Undang Dasar, Pasal 3 ayat (2) Undang-Undang RI Nomor 10 Tahun 2004, menentukan:

"Undang-Undang Dasar Negara Republik Indonesia Tahun 1945 ditempatkan dalam Lembaran Negara Republik Indonesia".

Jadi, menurut Pasal 3 ayat (2) Undang-Undang tersebut, UndangUndang Dasar dan Perubahan-perubahannya wajib diundangkan/diumumkan. Apabila tidak diundangkan, maka UndangUndang Dasar dan Perubahan-perubahannya tidak mempunyai kekuatan hukum mengikat. Pasal 3 ayat (3) Undang-Undang RI Nomor 10 Tahun 2004, menentukan:

"Penempatan Undang-Undang Dasar Negara Republik Indonesia Tahun 1945 dalam Lembaran Negara Republik Indonesia tidak merupakan dasar pemberlakuan".

Dalam penggunaan teori pengundangan/pengumuman peraturan perundang-undangan atau teori promulgasi tersebut antara lain dapat ditemukan dalam "Ketentuan Penutup", Pasal 58 Undang-Undang RI Nomor 10 Tahun 2004, yang menentukan:

"Agar setiap orang mengetahuinya, memerintahkan pengundangan Undang-Undang ini dengan penempatannya dalam Lembaran Negara Republik Indonesia".

\section{B. Teori Notifikasi Hukum Konstitusi}

Guna menunjang asas fiksi hukum "semua orang di anggap tahu hukum" dan asas hukum "peraturan-peraturan yang telah dibuat harus diumumkan", pemahaman hukum secara luas, serta efektivitas hukum; maka dapat dilakukan dengan penyebarluasan pemahaman peraturan 
perundang-undangan (legal notification). Ini sesuai dengan teori penyebarluasan pemahaman peraturan perundang-undangan (legal notification ${ }^{8}$ theory) yang menyatakan suatu peraturan perundangundangan yang telah diundangkan/diumumkan lebih diketahui serta isi dan maksud-maksud yang terkandung di dalamnya lebih dimengerti/dipahami oleh khalayak ramai melalui penyebarluasan pemahaman peraturan perundang-undangan. Notifikasi Hukum Konstitusi adalah penyebarluasan pemahaman Hukum Dasar, baik Hukum Dasar tertulis maupun Hukum Dasar tidak tertulis. Atau notifikasi Hukum Konstitusi adalah penyebarluasan pemahaman peraturan perundang-undangan konstitutif atau peraturan-peraturan legal konstitutif ataupun peraturan-peraturan non legal/ekstra legal konstitutif.

Ketentuan yang mewajibkan penyerbarluasan pemahaman peraturan perundang-undangan tadi, diatur dalam Pasal 51 Bagian Kedua Penyebarluasan Undang-Undang RI Nomor 10 Tahun 2004, yang menentukan:

"Pemerintah wajib menyebarluaskan Peraturan Perundang-undangan yang telah diundangkan dalam Lembaran Negara Republik Indonesia atau Berita Negara Republik Indonesia".

Adapun yang dimaksud dengan "peraturan perundang-undangan" Pasal 1 angka 2 Undang-Undang RI Nomor 10 Tahun 2004, merumuskan:

"Peraturan Perundang-undangan adalah peraturan tertulis yang dibentuk oleh lembaga negara atau pejabat yang berwenang dan mengikat secara umum".

Bagir Manan mendefinisikan:

"Peraturan perundang-undangan adalah kaidah hukum tertulis yang dibuat pejabat yang berwenang atau lingkungan jabatan yang berwenang yang berisi aturanaturan tingkah laku yang bersifat abstrak dan mengikat

${ }^{8}$ Bandingkan John M. Echols dan Hassan Shadily, Ibid., hal. 397, mengartikan: notice adalah pemberitahuan, maklumat, pengumuman misal pengumuman di surat kabar; to serve notice adalah memaklumkan; notification adalah pemberitahuan, pengumuman; notify, notified adalah memberitahu, memberitahukan.

Departemen Pendidikan dan Kebudayaan RI, Kamus Besar Bahasa Indonesia, Edisi Kedua, Cetakan Ketiga, (Jakarta: Balai Pustaka, 1994), hal. 694, mengartikan: notifikasi adalah pemberitahuan, kabar. 
(secara) umum. Peraturan yang dibuat pejabat berwenang (ambtsdrager) misalnya Peraturan Pemerintah, Peraturan Menteri. Peraturan yang dibuat oleh lingkungan jabatan (organ) misalnya Ketetapan MPR". ${ }^{9}$

Penjelasan Pasal 51 Undang-Undang RI Nomor 10 Tahun 2004, menerangkan :

"Yang dimaksud dengan "menyebarluaskan" adalah agar khalayak ramai mengetahui peraturan perundangundangan tersebut dan mengerti/memahami isi serta maksud-maksud yang terkandung di dalamnya. Penyebarluasan peraturan perundang-undangan tersebut dilakukan; misalnya, melalui media elektronik seperti Televisi Republik Indonesia dan Radio Republik Indonesia atau media cetak".

Penyebarluasan pemahaman tidak hanya terhadap peraturan perundang-undangan, tetapi juga terhadap rancangan undang-undang, sebagaimana diatur dalam Pasal 22 ayat (1) dan ayat (2) UndangUndang RI Nomor 10 Tahun 2004. Pasal 22 ayat (1), menentukan :

"Penyerbarluasan rancangan undang-undang yang berasal dari Dewan Perwakilan Rakyat dilaksanakan oleh Sekretaris Jenderal Dewan Perwakilan Rakyat". Pasal 22 ayat (2), menentukan : "Penyebarluasan rancangan undang-undang yang berasal dari Presiden dilaksanakan oleh instansi pemrakarsa".

Penyebarluasan pemahaman rancangan undang-undang dapat dimaknai penyebarluasan pemahaman rancangan peraturan perundangundangan konstitutif atau rancangan peraturan-peraturan legal konstitutif.

Penyebarluasan pemahaman juga berlaku untuk Peraturan Daerah. Pasal 136 ayat (5) Undang-Undang RI Nomor 32 Tahun 2004 tentang Pemerintahan Daerah, menentukan Peraturan Daerah ditetapkan oleh kepala daerah setelah mendapat persetujuan bersama Dewan Perwakilan Rakyat Daerah (DPRD). Peraturan Daerah dibentuk dalam rangka penyelenggaraan otonomi daerah provinsi/kabupaten/kota dan tugas pembantuan (Ayat (2)). Peraturan Daerah merupakan penjabaran lebih lanjut dari peraturan perundang-undangan yang lebih tinggi

9 Bagir Manan, "Teori dan Politik Konstitusi", Cetakan Kedua, (Yogyakarta Fakultas Hukum UII Press, 2004), hal. 211-212. 
dengan memperhatikan ciri khas masing-masing daerah (Ayat (3)). Peraturan Daerah dilarang bertentangan dengan kepentingan umum dan/atau peraturan perundang-undangan yang lebih tinggi (Ayat (4)). Peraturan Daerah berlaku setelah diundangkan dalam lembaran daerah (Ayat (3)). Pasal 52 Bagian Kedua Penyebarluasan Undang-Undang RI Nomor 10 Tahun 2004, menentukan : "Pemerintah Daerah wajib menyebarluaskan Peraturan Daerah yang telah diundangkan dalam Lembaran Daerah dan peraturan di bawahnya yang telah diundangkan dalam Berita Daerah".

Penjelasan Pasal 52 Undang-Undang RI Nomor 10 Tahun 2004, menerangkan: "Yang dimaksud dengan "menyebarluaskan" adalah agar khalatak ramai mengetahui peraturan perundang-undangan di daerah yang bersangkutan dan mengerti/memahami isi serta maksud-maksud yang terkandung di dalamnya. Penyebarluasan peraturan perundang-undangan tersebut dilakukan; misalnya melalui media elektronik seperti Televisi Republik Indonesia dan Radio Republik Indonesia, stasiun radio daerah, atau media cetak yang terbit di daerah yang bersangkutan".

Dalam penggunaan teori penyebarluasan pemahaman peraturan perundang-undangan daerah tersebut antara lain dapat ditemukan dalam "Ketentuan Lain dan Penutup", Pasal 49 Peraturan Daerah Kota Bandung Nomor 20 Tahun 2002 tentang Penyelenggaraan Pendidikan, yang menentukan :

"Agar supaya setiap orang dapat mengetahuinya memerintahkan pengundangan Peraturan Daerah ini dengan penempatannya dalam Lembaran Daerah Kota Bandung".

Penyebarluasan pemahaman tidak hanya terhadap peraturan daerah, tetapi juga terhadap rancangan peraturan daerah, sebagaimana diatur dalam Pasal 30 ayat (1) dan ayat (2) Undang-Undang RI Nomor 10 Tahun 2004. Pasal 30 ayat (1), menentukan:

"Penyebarluasan rancangan peraturan daerah yang berasal dari Dewan Perwakilan Rakyat Daerah dilaksanakan oleh Sekretariat Dewan Perwakilan Rakyat Daerah".

Pasal 30 ayat (2), menentukan: 
"Penyebarluasan rancangan peraturan daerah yang berasal dari Gubernur atau Bupati/Walikota dilaksanakan oleh Sekretariat Daerah".

Penyebarluasan pemahaman rancangan peraturan daerah dapat dimaknai penyebarluasan pemahaman rancangan peraturan perundangundangan daerah konstitutif atau peraturan-peraturan daerah legal konstitutif.

\section{Notifikasi Hukum Konstitusi Melalui Pendidikan}

Notifikasi Hukum Konstitusi antara lain dapat dilakukan melalui pendidikan. Dalam tulisan ini definisi atau rumusan pendidikan meminjam dari Undang-Undang RI Nomor 2 Tahun 1989 tentang Sistem Pendidikan Nasional (Sisdiknas) yang telah dicabut dan digantikan oleh Undang-Undang RI Nomor 20 Tahun 2004 tentang Sistem Pendidikan Nasional. Menurut Pasal 1 angka 1 Undang-Undang RI Nomor 2 Tahun 1989 tentang Sistem Pendidikan Nasional (Sisdiknas):

"Pendidikan adalah usaha sadar untuk menyiapkan peserta didik melalui kegiatan bimbingan, pengajaran, dan/atau latihan bagi peranannya di masa yang akan datang".

Jadi, menurut rumusan pendidikan tersebut, usaha pendidikan bisa melalui tiga jenis kegiatan, yaitu bimbingan, pengajaran, dan latihan atau pelatihan. Begitu pula dalam pendidikan Hukum Konstitusi melalui ketiga kegiatan tadi.

Adapun yang dimaksud dengan pendidikan Hukum Konstitusi adalah proses transfer bahan konstitusi dari pendidik kepada peserta didik guna memperoleh pengetahuan, sikap, dan keterampilan mengenai konstitusi berlandaskan teori-teori pendidikan, belajar mengajar (pembelajaran), dan psikologi perkembangan dengan metode didukung sumber belajar mengajar yang relevan. Melalui proses menanamkan pengetahuan, sikap, dan keterampilan mengenai bahan konstitusi dapat menunjang dalam menegakkan Negara Hukum Kesejahteraan yang Demokratis guna menopang dan mengokohkan bangunan Negara sebagai organisasi puncak atau asosiasi supra dalam tata hukum nasional.

Notifikasi Hukum Konstitusi (notification of The Law of the Constitution) melalui pendidikan dapat melalui jalur pendidikan formal, pendidikan nonformal, dan pendidikan informal. 


\section{A. Notifikasi Hukum Konstitusi Melalui Jalur Pendidikan Formal}

Notifikasi Hukum Konstitusi dapat dilakukan melalui jalur pendidikan formal (formal education).

\section{Notifikasi Hukum Konstitusi Melalui Pendidikan Dasar dan Pendidikan Menengah}

Pasal 1 angka 11 Undang-Undang RI Nomor 20 Tahun 2003 tentang Sistem Pendidikan Nasional (Sisdiknas), merumuskan pendidikan formal adalah jalur pendidikan yang terstruktur dan berjenjang terdiri atas pendidikan dasar, pendidikan menengah, dan pendidikan tinggi.

Pasal 17 ayat (1) Undang-Undang RI Nomor 20 Tahun 2003, menentukan pendidikan dasar merupakan jenjang pendidikan yang melandasi jenjang pendidikan menengah. Pasal 17 ayat (2) Undang-Undang RI Nomor 20 Tahun 2003, menentukan bentuk pendidikan dasar, yaitu Sekolah Dasar (SD), Madrasah Ibtidaiyah (MI), atau bentuk lain yang sederajat, serta Sekolah Menengah Pertama (SMP), Madrasah Tsanawiyah (MTs), atau bentuk lain yang sederajat. Penjelasan Pasal 17 ayat (2) menerangkan pendidikan yang sederajat dengan $\mathrm{SD} / \mathrm{MI}$ adalah program seperti Paket A dan sederajat dengan SMP/MTs adalah program seperti Paket B.

Pasal 18 ayat (1) Undang-Undang RI Nomor 20 tahun 2003, menentukan pendidikan menengah merupakan lanjutan pendidikan dasar. Pendidikan menengah terdiri atas pendidikan menengah umum dan pendidikan menengah kejuruan (Pasal 18 ayat (2) Undang-Undang RI Nomor 20 Tahun 2003). Pasal 18 ayat (3) Undang-Undang RI Nomor 20 Tahun 2003, menentukan bentuk pendidikan menengah, yaitu Sekolah Menengah Atas (SMA), Madrasah Aliyah (MA), Sekolah Menengah Kejuruan (SMK), dan Madrasah Aliyah Kejuruan (MAK), atau bentuk lain yang sederajat. Penjelasan Pasal 18 ayat (3) menerangkan pendidikan yang sederajat dengan SMA/MA adalah program seperti paket C.

\section{Notifikasi Hukum Konstitusi Melalui Pendidikan Tinggi}

Pasal 19 ayat (1) Undang-Undang RI Nomor 20 Tahun 2003, menentukan pendidikan tinggi merupakan jenjang pendidikan setelah pendidikan menengah yang mencakup program 
pendidikan diploma, sarjana, magister, spesialis, dan doktor yang diselenggarakan oleh perguruan tinggi. Pasal 1 angka 2 Peraturan Pemerintah RI Nomor 60 Tahun 1999, merumuskan perguruan tinggi adalah satuan pendidikan yang menyelenggarakan pendidikan tinggi. Pasal 20 ayat (1) Undang-Undang RI Nomor 20 Tahun 2003, menentukan perguruan tinggi berbentuk akademi, politeknik, sekolah tinggi, institut, atau universitas. Pasal 20 ayat (3) Undang-Undang RI Nomor 20 Tahun 2003, menentukan perguruan tinggi dapat menyelenggarakan program akademik, profesi, dan/atau vokasi.

Notifikasi Hukum Konstitusi dalam arti luas tidak hanya berarti penyebarluasan pemahaman Hukum Dasar dalam bentuk peraturan perundang-undangan konstitutif atau peraturanperaturan legal konstitutif dan peraturan-peraturan legal/ekstra legal konstitutif, melainkan meliputi pula penyebarluasan pemahaman keilmuan Hukum Konstitusi. Hal itu terutama berlangsung, baik di dalam perguruan tinggi maupun di luar perguruan tinggi, tetapi terutama sekali di dalam perguruan tinggi.

Notifikasi Hukum Konstitusi di perguruan tinggi dapat melalui kegiatan-kegiatan atau usaha pendidikan, penelitian, dan pengabdian kepada masyarakat. Ketiga kegiatan ini disebut tri dharma perguruan tinggi. Kegiatan-kegiatan ini dapat berlangsung di dalam perguruan tinggi dan di luar perguruan tinggi. Pasal 20 ayat (2) Undang-Undang RI Nomor 20 Tahun 2003, menentukan perguruan tinggi berkewajiban menyelenggarakan pendidikan, penelitian, dan pengabdian kepada masyarakat. Pasal 3 ayat (3) Peraturan Pemerintah RI Nomor 60 Tahun 1999 tentang Pendidikan Tinggi, menentukan perguruan tinggi menyelenggarakan pendidikan tinggi dan penelitian serta pengabdian kepada masyarakat.

\section{a. Notifikasi Hukum Konstitusi Melalui Pendidikan di Perguruan Tinggi}

Meminjam definisi atau rumusan pendidikan dari Pasal 1 angka 1 Undang-Undang RI Nomor 2 Tahun 1999, usaha pendidikan melalui kegiatan-kegiatan bimbingan, pengajaran, dan pelatihan. Usaha pendidikan Hukum Konstitusi dapat dilakukan melalui kegiatan-kegiatan pendidikan di dalam dan di luar perguruan tinggi. Di dalam perguruan tinggi, usaha pendidikan Hukum Konstitusi dilakukan melalui pendidikan formal. Di luar perguruan tinggi, untuk pendidikan Hukum 
Konstitusi dapat dilakukan melalui kegiatan-kegiatan pendidikan formal, pendidikan nonformal, dan pendidikan informal.

Di dalam perguruan tinggi, notifikasi Hukum Konstitusi melalui usaha pendidikan dapat melalui hand out, diktat, modul, silabus, satuan pelajaran, dan sejenisnya. Di samping itu, melalui laporan penelitian skripsi, tesis, dan disertasi. Di luar perguruan tinggi, dapat melalui berita, feature, dan artikel untuk media massa cetak (buletin, majalah, tabloid, dan surat kabar) dan media massa elektronik (radio, televisi, film, dan internet), artikel untuk media massa cetak dan elektronik, artikel untuk jurnal, serta buku.

\section{a. Notifikasi Hukum Konstitusi Melalui Penelitian di Perguruan Tinggi}

Usaha penelitian Hukum Konstitusi dapat dilakukan melalui kegiatan-kegiatan penelitian di dalam perguruan tinggi dan di luar perguruan tinggi. Di dalam perguruan tinggi, penelitian Hukum Konstitusi dapat melalui penelitian latihan, penelitian hubungan antarilmu, penelitian manajemen kelembagaan, dan penelitian pembangunan. Di luar perguruan tinggi, penelitian Hukum Konstitusi antara lain dapat dilakukan oleh lembaga-lembaga penelitian, baik yang dikelola oleh pemerintah maupun yang dikelola oleh masyarakat.

Di dalam perguruan tinggi, notifikasi Hukum Konstitusi melalui usaha penelitian dapat melalui laporan penelitian, artikel untuk jurnal, makalah, dan buku. Di luar perguruan tinggi, dapat melalui berita, feature, dan artikel untuk media massa cetak dan elektronik, serta artikel untuk jurnal.

\section{b. Notifikasi Hukum Konstitusi Melalui Pengabdian Kepada Masyarakat di Perguruan Tinggi}

Usaha pengabdian kepada masyarakat Hukum Konstitusi dapat dilakukan melalui kegiatan-kegiatan pengabdian kepada masyarakat di perguruan tinggi dan di luar perguruan tinggi. Di dalam perguruan tinggi pengabdian kepada masyarakat Hukum Konstitusi dapat melalui kegiatan-kegiatan pendidikan masyarakat, pelayanan masyarakat, penelitian tindakan (action research), kuliah kerja nyata, praktik kerja lapangan, dan kegiatan lain yang sejenis. Di luar perguruan tinggi, pengabdian kepada masyarakat Hukum Konstitusi antara lain dapat dilakukan oleh lembaga-lembaga hukum, baik yang dikelola oleh pemerintah maupun yang dikelola oleh masyarakat. 
Di dalam perguruan tinggi, notifikasi Hukum Konstitusi melalui usaha pengabdian kepada masyarakat dapat dilakukan melalui laporan pengabdian kepada masyarakat, artikel untuk jurnal, makalah, dan buku. Di luar perguruan tinggi, dapat melalui berita, feature, dan artikel untuk media massa cetak dan elektronik, serta artikel untuk jurnal.

\section{B. Notifikasi Hukum Konstitusi Melalui Jalur Pendidikan Nonformal}

Notifikasi Hukum Konstitusi dapat dilakukan melalui jalur pendidikan nonformal (nonformal education).

Pasal 1 angka 12 Undang-Undang RI Nomor 20 Tahun 2003, menentukan pendidikan nonformal adalah jalur pendidikan di luar jalur pendidikan formal yang dapat dilaksanakan secara terstruktur dan berjenjang. Pasal 26 ayat (1), menentukan pendidikan nonformal diselenggarakan bagi warga masyarakat yang memerlukan layanan pendidikan yang berfungsi sebagai pengganti, penambah, dan/atau pelengkap pendidikan formal dalam rangka mendukung pendidikan sepanjang hayat. Pasal 26 ayat (2), menentukan pendidikan nonformal berfungsi mengembangkan potensi peserta didik dengan penekanan pada penguasaan pengetahuan dan keterampilan fungsional serta pengembangan sikap dan kepribadian profesional.

Lingkup pendidikan nonformal diatur dalam Pasal 26 ayat (3) dan ayat (4) Undang-Undang RI Nomor 20 Tahun 2003. Pasal 26 ayat (3), menentukan pendidikan nonformal meliputi pendidikan kecakapan hidup, pendidikan anak usia dini (PAUD), pendidikan kepemudaan, pendidikan pemberdayaan perempuan, pendidikan keaksaraan, pendidikan keterampilan dan pelatihan kerja, pendidikan kesetaraan, serta pendidikan lain yang ditujukan untuk mengembangkan kemampuan peserta didik. Pasal 26 ayat (4), menentukan satuan pendidikan nonformal terdiri atas lembaga kursus, lembaga pelatihan, kelompok belajar, pusat kegiatan belajar masyarakat, majelis taklim, dan satuan pendidikan yang sejenis.

Kursus dan pelatihan diselenggarakan bagi masyarakat yang memerlukan bekal pengetahuan, keterampilan, kecakapan hidup, dan sikap untuk mengembang- kan diri, mengembangkan profesi, bekerja, usaha mandiri, dan/atau melanjutkan pendidikan ke jenjang yang lebih tinggi (Pasal 26 ayat (5) Undang-Undang Nomor 20 Tahun 2003). Hasil pendidikan nonformal dapat dihargai setara dengan hasil program pendidikan formal setelah melalui proses penilaian penyetaraan oleh lembaga yang ditunjuk oleh Pemerintah atau 
Pemerintah Daerah dengan mengacu pada standar nasional pendidikan (Pasal 26 ayat (6) Undang-Undang Nomor 20 Tahun 2003).

\section{Notifikasi Hukum Konstitusi Melalui Jalur Pendidikan Informal}

Notifikasi Hukum Konstitusi dapat dilakukan melalui jalur pendidikan informal (informal education).

Pasal 1 angka 13 Undang-Undang RI Nomor 20 Tahun 2003, menentukan pendidikan informal adalah jalur pendidikan keluarga dan lingkungan. Pasal 27 ayat (1) Undang-Undang RI Nomor 20 Tahun 2003), menentukan kegiatan pendidikan informal yang dilakukan oleh keluarga dan lingkungan berbentuk kegiatan belajar secara mandiri.

Salah satu bentuk kegiatan belajar secara mandiri dalam pendidikan informal, yaitu sekolah rumah (home schooling). Sekolah rumah memiliki sejarah yang cukup panjang. Kegiatan ini mulai dikenalkan di Amerika Serikat tahun 1836. Tujuan utamanya adalah menciptakan suasana belajar bagi anak yang bebas dari tekanan tidak pantas yang biasanya dialami anak di sekolah umum. Yang lebih penting, orang tua dapat mengawasi kegiatan belajar anak-anak mereka, sehingga mereka dapat memberikan layanan pendidikan yang optimal bagi putra-putri kesayangannya. Tokoh utama yang mengembangkan home schooling di Amerika Serikat adalah Jhon Holt (1923-1985). Home schooling di Amerika Serikat pernah mengalami kemunduran sejalan dengan diwajibkannya kegiatan belajar di sekolah umum (public schools) di bawah naungan pemerintah. Beberapa dekade terakhir home schooling di Amerika Serikat mengalami pertambahan pada orang tua yang menyekolahkan anak-anak mereka di rumah. Imbasnya sampai ke Indonesia. Susanah Shefeer memaparkan tahun 1980-an di Kota Boston terdapat kurang lebih 20.000 keluarga yang menyelenggarakan kegiatan sekolah rumah untuk 50.000 anak-anak mereka. Data terakhir menyebutkan di Amerika Serikat kurang lebih 1,35 juta anak mengikuti sekolah rumah. $^{10}$

Beberapa alasan orang tua di Amerika Serikat menyelenggarakan home schooling: (1) orang tua khususnya ibu memiliki waktu yang cukup untuk tinggal di rumah, sehingga mereka lebih mampu

${ }^{10}$ Lihat dan bandingkan Mubiar Agustis, Dosen Program PGTK UPI, Menggugat Eksistensi Sekolah Rumah, Harian Umum "Pikiran Rakyat", Bandung, Rabu, 19 Desember 2007, hal. 1 dan 6. 
mengeratkan ikatan dalam keluarga yang lebih stabil; (2) mereka tidak ingin menyerahkan pendidikan anak-anaknya kepada orang lain atau lembaga tertentu (sekolah); (3) mereka percaya anak akan belajar lebih baik apabila mereka menentukan sendiri apa yang akan dipelajari di sekolah rumah sebagai alternatif sekolah yang lebih kondusif dan alamiah; (4) ada juga orang tua yang ingin menyampaikan nilai-nilai agama yang cocok untuk anak-anak; dan (5) sebagian orang tua beranggapan sebelum usia 8 atau 10 tahun anak-anak tidak perlu mendapatkan tekanan fisik dan kognitif. ${ }^{11}$

Alasan orang tua di Amerika Serikat dan di Indonesia, bahkan diberbagai negara cenderung tidak jauh berbeda. Mereka menyelenggarakan home schooling, karena ketidakpuasan terhadap layanan yang diberikan sekolah. Terdapat kecenderungan pula orang tua terdorong ingin mencoba metode baru dalam pembelajaran bagi pendidikan anak-anak mereka.

Beberapa hal yang perlu diperhatikan dalam kaitannya dengan penyelenggaraan sekolah rumah bahwa usia anak-anak adalah usia bermain, usia sekolah, usia awal berkelompok, usia bertanya, dan usia meniru. Mereka dalam masa emas untuk membangun hubungan dengan teman sebayanya. Home schooling di Amerika Serikat cenderung untuk anak-anak yang berusia 6-10 tahun, sedangkan sekolah rumah di Indonesia cenderung untuk semua kelompok usia anak sampai dengan usia sekolah menengah atas. ${ }^{12}$

Hasil pendidikan informal diakui sama dengan pendidikan formal dan pendidikan nonformal setelah peserta didik lulus ujian sesuai dengan standar nasional pendidikan. Pasal 1 angka 14 Undang-Undang RI Nomor 20 Tahun 2003, merumuskan pendidikan anak usia dini (PAUD) adalah suatu upaya pembinaan yang ditujukan kepada anak sejak lahir sampai dengan usia enam tahun yang dilakukan melalui pemberian rangsangan pendidikan untuk membantu pertumbuhan dan perkembangan jasmani dan rohani agar anak memiliki kesiapan dalam memasuki pendidikan lebih lanjut.

Pasal 28 Undang-Undang RI Nomor 20 Tahun 2003 mengatur PAUD. Pasal 28 ayat (1), menentukan PAUD diselenggarakan sebelum jenjang pendidikan dasar. Penjelasan Pasal 28 ayat (1) menerangkan PAUD diselenggarakan bagi anak sejak lahir sampai dengan enam tahun dan bukan merupakan prasyarat untuk mengikuti

\footnotetext{
${ }^{11}$ Lihat dan bandingkan Mubiar Agustis, Ibid., hal. 6.

${ }^{12}$ Ibid.
} 
pendidikan dasar. Berdasarkan Pasal 1 angka 11 yang merumuskan pendidikan formal terdiri atas pendidikan dasar, pendidikan menengah, dan pendidikan tinggi jo Pasal 1 angka 12 yang merumuskan pendidikan nonformal merupakan pendidikan di luar pendidikan formal jo Pasal 26 ayat (3) yang menentukan pendidikan nonformal antara lain PAUD jo Pasal 28 ayat (1) yang menentukan PAUD merupakan pendidikan sebelum jenjang pendidikan dasar, maka PAUD bukan pendidikan formal dan juga bukan pendidikan informal; melainkan pendidikan nonformal. Jadi, PAUD masuk ke dalam pendidikan nonformal.

Selanjutnya, Pasal 28 ayat (2) Undang-Undang RI Nomor 20 Tahun 2003, menentukan PAUD dapat diselenggarakan melalui jalur pendidikan formal, pendidikan nonformal, dan/atau pendidikan informal. Artinya, meskipun PAUD sebagai pendidikan nonformal, tetapi penyelenggaraannya dapat pada jalur pendidikan formal, pada jalur pendidikan nonformal, dan/atau pada jalur pendidikan informal. Pasal 28 ayat (3), menentukan PAUD pada jalur pendidikan formal berbentuk Taman Kanak-kanak (TK), Raudhatul Athfal (RA), atau bentuk lain yang sederajat. Penjelasan Pasal 28 ayat (3), menerangkan TK menyelenggarakan pendidikan untuk mengembangkan kepribadian dan potensi diri sesuai dengan tahap perkembangan peserta didik. $R A$ menyelenggarakan pendidikan keagamaan Islam yang menanamkan nilai-nilai keimanan dan ketakwaan kepada peserta didik untuk mengembangkan potensi diri seperti pada TK. Pasal 28 ayat (4) menentukan PAUD pada jalur pendidikan nonformal berbentuk Kelompok Bermain (KB), Taman Penitipan Anak (TPA), atau bentuk lain yang sederajat. Pasal 28 ayat (5), menentukan PAUD pada jalur pendidikan informal berbentuk pendidikan keluarga atau pendidikan yang diselenggarakan oleh lingkungan.

Pasal 15 Undang-Undang RI Nomor 20 Tahun 2003, menentukan jenis pendidikan mencakup pendidikan umum, kejuruan, akademik, profesi, vokasi, keagamaan, dan khusus. Penjelasan Pasal 15 UndangUndang RI Nomor 20 Tahun 2003 menerangkan jenis-jenis pendidikan tersebut. Pendidikan umum merupakan pendidikan dasar dan menengah yang mengutamakan perluasan pengetahuan yang diperlukan oleh peserta didik untuk melanjutkan pendidikan ke jenjang yang lebih tinggi. Pendidikan kejuruan merupakan pendidikan menengah yang mempersiapkan peserta didik terutama untuk bekerja dalam bidang tertentu. Pendidikan akademik merupakan pendidikan tinggi program sarjana dan pascasarjana yang diarahkan terutama pada penguasaan disiplin ilmu pengetahuan tertentu. Pendidikan profesi 
merupakan pendidikan tinggi setelah program sarjana yang mempersiapkan peserta didik untuk memiliki pekerjaan dengan persyaratan keahlian khusus. Pendidikan vokasi merupakan pendidikan tinggi yang mempersiapkan peserta didik untuk memiliki pekerjaan dengan keahlian terapan tertentu maksimal setara dengan program sarjana. Pendidikan keagamaan merupakan pendidikan dasar, menengah, dan tinggi yang mempersiapkan peserta didik untuk dapat menjalankan peranan yang menuntut penguasaan pengetahuan tentang ajaran agama dan/atau menjadi ahli ilmu agama. Pendidikan khusus merupakan penyelenggaraan pendidikan untuk peserta didik yang berkelainan atau peserta didik yang memiliki kecerdasan luar biasa yang diselenggarakan secara inklusif atau berupa satuan pendidikan khusus pada tingkat pendidikan dasar dan menengah.

Di samping mengatur jenis pendidikan tersebut, Undang-Undang Nomor 20 Tahun 2003, mengatur pula pendidikan kedinasan (Pasal 29), pendidikan keagamaan (Pasal 30), pendidikan jarak jauh (Pasal 31), dan pendidikan khusus dan pendidikan layanan khusus (Pasal 32). Pasal 29, menentukan pendidikan kedinasan merupakan pendidikan profesi yang diselenggarakan oleh departemen atau lembaga pemerintah nondepartemen. Pendidikan kedinasan berfungsi meningkatkan kemampuan dan keterampilan dalam pelaksanaan tugas kedinasan bagi pegawai dan calon pegawai negeri suatu departemen atau lembaga pemerintah nondepartemen. Pendidikan kedinasan diselenggarakan melalui jalur pendidikan formal dan pendidikan nonformal.

Pasal 30, menentukan pendidikan keagamaan diselenggarakan oleh Pemerintah dan/atau kelompok masyarakat dari pemeluk agama, sesuai dengan peraturan perundang-undangan. Pendidikan keagamaan berfungsi mempersiapkan peserta didik menjadi anggota masyarakat yang memahami dan mengamalkan nilai-nilai ajaran agama dan/atau menjadi ahli ilmu agama. Pendidikan keagamaan dapat diselenggarakan pada jalur pendidikan formal, pendidikan nonformal, dan pendidikan informal. Pendidikan keagamaan berbentuk pendidikan diniyah, pesantren, pasraman, pabhaja samanera, dan bentuk lain yang sejenis.

Pasal 31, menentukan pendidikan jarak jauh dapat diselenggarakan pada semua jalur, jenjang, dan jenis pendidikan. Pendidikan jarak jauh berfungsi memberikan layanan pendidikan kepada kelompok masyarakat yang tidak dapat mengikuti pendidikan secara tatap muka atau reguler. Pendidikan jarak jauh diselenggarakan dalam berbagai bentuk, modus, dan cakupan yang didukung oleh 
sarana dan layanan belajar serta sistem penilaian yang menjamin mutu lulusan sesuai dengan standar nasional pendidikan.

Pasal 32, menentukan pendidikan khusus merupakan pendidikan bagi peserta didik yang memiliki tingkat kesulitan dalam mengikuti proses pembelajaran, karena kelainan fisik, emosional, mental, sosial, dan/atau memiliki potensi kecerdasan dan bakat istimewa. Pendidkan layanan khusus merupakan pendidikan bagi peserta didik di daerah terpencil atau terbelakang, masyarakat adat yang terpencil, dan/atau mengalami bencana alam, bencana sosial, dan tidak mampu dari segi ekonomi.

\section{Pendidikan Kewarganegaraan Dalam Kurikulum Pendidikan}

Pendidikan Kewarganegaraan akan mempunyai kekuatan hukum dengan mendapat legitimasi hukum. Hal itu mengingat hukum merupakan proses akhir dari de facto ke de jure. Hukum menjamin ketertiban hukum, kepastian hukum, dan perlindungan hukum. Dengan diatur hukum segala pelaksanaan dan perubahan diarahkan berjalan teratur. Kemampuan hukum seperti itulah, maka hukum sebagai alat/sarana/instrumen perubahan/ pembangunan masyarakat (law as a tool of social engineering). Pengembangan bahan-bahan Pendidikan Kewarganegaraan termasuk bahanbahan Hukum Konstitusi di dalamnya memerlukan rambu-rambu pegangan hukum. Dengan pengaturan itu, pelaksanaan transfer bahan-bahan tadi berlangsung secara relatif homogin.

Menurut Pasal 37 ayat (1) huruf b Undang-Undang RI Nomor 20 Tahun 2003, kurikulum pendidikan dasar dan menengah wajib memuat pendidikan kewarganegaraan. Pasal 37 ayat (2) huruf b Undang-Undang RI tersebut, menentukan kurikulum pendidikan tinggi wajib memuat pendidikan kewarga-negaraan. Jadi, dalam kurikulum pendidikan formal, baik kurikulum pendidikan dasar, kurikulum pendidikan menengah, maupun kurikulum pendidikan tinggi wajib memuat pendidikan kewarganegaraan. Pendidikan kewarganegaraan dalam kurikulum pendidikan nonformal dan kurikulum pendidikan informal menyesuaikan dengan kebutuhan.

Hal itu berarti, pendidikan kewargenageraan wajib diajarkan pada : (1) pendidikan dasar yang meliputi SD, MI, atau bentuk lain yang sederajat seperti program Paket A serta SMP, MTs, atau bentuk lain yang sederajat seperti program Paket B; (2) pendidikan menengah yang meliputi SMA, MA, SMK, MAK, atau bentuk lain yang sederajat seperti yang sederajat dengan SMA/MA berupa program Paket C; dan (3) pendidikan tinggi yang meliputi akademi, politeknik, sekolah tinggi, institusi, dan universitas. 
Pendidikan kewarganegaraan dapat diajarkan pada pendidikan nonformal sesuai dengan keadaan dan kebutuhan yang meliputi pendidikan kecakapan hidup, pendidikan anak usia dini (PAUD), pendidikan kepemudaan, pendidikan pemberdayaan perempuan, pendidikan keaksaraan, pendidikan keterampilan dan pelatihan kerja, pendidikan kesetaraan, serta pendidikan lain yang ditujukan untuk mengembangkan kemampuan peserta didik. Satuan pendidikan nonformal meliputi lembaga kursus, lembaga pelatihan, kelompok belajar, pusat kegiatan belajar masyarakat, majelis taklim, dan satuan pendidikan yang sejenis. Satuan pendidikan anak usia dini (PAUD) meliputi TK, $R A$, atau bentuk lain yang sederajat serta $\mathrm{KB}$, TPA, atau bentuk lain yang sederajat.

Pendidikan kewarganegaraan dapat diajarkan pada pendidikan informal sebagai kegiatan yang dilakukan oleh keluarga dan lingkungan berbentuk kegiatan belajar secara mandiri sesuai dengan keadaan dan kebutuhan seperti pada sekolah rumah (home schooling).

Dilihat dari segi jenis-jenis pendidikan, sesuai dengan keadaan dan kebutuhan, pendidikan kewarganeagraan diajarkan pada pendidikan umum, pendidikan kejuruan, pendidikan akademik, pendidikan profesi, pendidikan vokasi, pendidikan keagamaan, dan pendidikan khusus. Di samping itu, sesuai dengan keadaan dan kebutuhan, pendidikan kewarganegaraan diajarkan pada pendidikan kedinasan, pendidikan jarak jauh, dan pendidikan layanan khusus.

Ditinjau dari segi pendidikan demokrasi ${ }^{13}$, pendidikan kewarganegaraan merupakan bagian dari pendidikan demokrasi. Hal itu dapat dilihat dari International Commission of Jurists pada South-East Asian and Pacific Conference of Jurists-nya di Bangkok pada tahun 1965 yang merumuskan syarat-syarat (ciri-ciri) pemerintahan yang demokratis di bawah Rule of Law yang dinamis sebagai berikut : (1) perlindungan konstitusional, artinya selain menjamin hak-hak individu, konstitusi harus pula menentukan cara prosedural untuk memperoleh perlindungan atas hak-hak yang dijamin; (2) badan kehakiman yang bebas dan tidak memihak; (3) pemilihan umum yang bebas; (4) kebebasan menyatakan pendapat; (5) kebebasan berserikat/berogranisasi dan beroposisi; serta (6) pendidikan kewarganegaraan. Menurut International Commission of Jurists tersebut,

${ }^{13}$ Hubungkan Bagir Manan, "Teori dan Politik Konstitusi", Op. Cit., hal. 142-143, mengemukakan: "Pendidikan merupakan instrumen pengembangan demokrasi yang sangat penting, yang akan meliputi, baik aspek-aspek konseptual maupun penerapannya. Tujuan terpenting pendidikan demokrasi adalah menumbuhkan kesadaran berdemokrasi, pengetahuan mengenai mekanisme demokrasi seperti democratic responsibility, fairness, transparancy, peaceful, moderate, dan lain-lain. Untuk mencapai tujuan tersebut, selain pendidikan konseptual harus diikuti pula latihan berdemokrasi". 
pendidikan kewarganegaraan merupakan salah satu syarat (ciri) dari pemerintahan yang demokratis yang dinamis. Oleh karena pendidikan kewarganageraan merupakan salah satu syarat (ciri) dari enam syarat (ciri) dari pemerintahan yang demokratis yang dinamis, maka pendidikan kewarganegaraan merupakan satu per enam dari syarat-syarat (ciri-ciri) pemerintahan yang demokratis yang dinamis tadi. Apakah suatu pemerintahan itu demokratis, kurang demokratis, atau tidak demokratis, tergantung pada seberapa jauh pemenuhan nilai-nilai demokrasi, yaitu persamaan, kebebasan, partisipasi, toleransi, transparansi, dan akuntabilitas publik.

Menurut Keputusan Dirjen Dikti Depdiknas RI Nomor 43/Dikti/Kep/2006 tentang Rambu-rambu Pelaksanaan Kelompok Mata Kuliah Pengembangan Kepribadian Di Perguruan Tinggi, meliputi (1) Filsafat Pancasila (Pancasila sebagai sistem filsafat dan Pancasila sebagai ideologi bangsa dan negara), (2) identitas nasional (karakteristik identitas nasional dan proses berbangsa dan bernegara), (3) politik dan strategi (sistem konstitusi serta sistem politik dan ketatanegaraan Indonesia), (4) demokrasi Indonesia (konsep dan prinsip demokrasi serta pendidikan demokrasi), (5) hak asasi manusia dan rule of law (hak asasi manusia dan rule of law), (6) hak dan kewajiban warga negara (warga negara Indonesia serta hak dan kewajiban warga negara Indonesia), (7) geopolitik Indonesia (wilayah sebagai ruang hidup dan otonomi daerah), serta (8) geostrategi Indonesia (konsep astra gatra serta Indonesia dan perdamaian dunia).

Pendidikan kewarganegaraan (civic education or citizenship education) sebagai bagian dari pendidikan demokrasi (democratic education) penting dalam mencapai tujuannya, yaitu pembentukan warga negara yang baik (good citizen making), pembangunan karakter dan bangsa (nation and character building), pembangsaan suatu bangsa misal pembangsaindonesiaan bangsa Indonesia (indonesianization), penguatan identitas nasional (national identity reinforecement), pengembangan kehidupan demokratis dan pemerintahan demokratis (democratic life and democratic government development), peningkatan kemakmuran perorangan dan kesejahteraan sosial (individual prosperity and social welfare enhancing), serta peningkatan kecerdasan dan keterampilan sosial (social skills and smartness enhancing).

\section{Pendidikan Hukum Konstitusi Dalam Pendidikan Kewarganegaraan}

Dalam pendidikan kewarganegaraan terdapat bahan Hukum Konstitusi. Oleh karena bahan Hukum Konstitusi berada dalam pendidikan kewarganegaraan, maka dapat diartikan bahan Hukum Konstitusi tersebut 
sebagai pendidikan Hukum Konstitusi. Tegasnya pendidikan Hukum Konstitusi dalam pendidikan kewarganegaraan.

Bahan belajar mengajar (pembelajaran) Hukum Konstitusi yang penting terutama bagi Negara Kesatuan Republik Indonesia yang menurut Pasal 18 UUD 1945 (2000) jo UU Nomor 32 Tahun 2004 tentang Pemerintahan Daerah melaksanakan model negara kesatuan dengan desentralisasi submodel negara kesatuan dengan desentralisasi yang federalistik mengandung kadar konfederalistik meliputi bahan-bahan pembentukan negara, norma dasar negara, kedaulatan dalam negara, negara hukum, negara kesejahteraan, negara demokrasi, negara kesatuan, pemerintahan republik, pemerintahan presidensil, penyelenggaraan pemerintahan daerah, dan penyelenggaraan otonomi daerah. Pemahaman atas bahan-bahan belajar mengajar (pembelajaran) Hukum Konstitusi akan menjadikan semua orang merasa optimis, merasa memiliki, dan merasa nyaman hidup di negara yang mereka cintai.

Persoalannya, bagaimana cara meramu bahan-bahan Hukum Konstitusi itu menjadi suatu kesatuan bahan yang fungsional, aktual, dan mempunyai daya tarik untuk dibaca, dicerna, dan dipelajari, bahkan dikaji dan diteliti oleh penerima atau pembacanya untuk segala strata usia dan keadaan pada jalur, jenjang, dan jenis pendidikan. Persoalan lain bagaimana cara menyelenggarakan bahan-bahan belajar mengajar (pembelajaran) Hukum Konstitusi tersebut dengan bahan-bahan Pendidikan Kewargenegaraan yang lain agar terpadu, sinergis, dan fungsional. Mengenai persoalan ini memerlukan pembahasan tersendiri.

VII. Sumbangan Pendidikan Hukum Konstitusi Terhadap Pendidikan Kewarganegaraan serta Kehidupan Negara, Bangsa, dan Masyarakat

\section{A. Sumbangan Pendidikan Hukum Konstitusi Terhadap Pendidikan Kewarganegaraan}

Dalam belajar mengajar (pembelajaran) Pendidikan Kewarganegaraan memerlukan dukungan bahan-bahan yang sesuai dengan tujuannya. Dalam rangka mencapai tujuannya, Pendidikan Kewarganegaraan tidak hanya mengandung bahan Hukum Konstitusi, melainkan mencakup bahan-bahan lainnya terutama mengenai Pancasila beserta Konstitusi turunannya sebagai inti dari semua bahan Pendidikan Kewarganegaraan. Di samping itu, bahan mengenai pendidikan kewarganegaraan itu sendiri. Bahan-bahan Pendidikan Kewarganegaraan lainnya seperti identitas nasional, politik dan 
strategi nasional, demokrasi Indonesia, hak asasi manusia, pemerintahan berdasarkan hukum (rule of law), hak dan kewajiban warga negara, geopolitik Indonesia, serta geostrategi Indonesia dapat disinergiskan secara fungsional sesuai dengan kebutuhan belajar mengajar (pembelajaran) Pendidikan Kewarganegaraan.

Sumbangan pendidikan Hukum Konstitusi terhadap Pendidikan Kewarganegaraan memperkuat komitmen warga negara akan supremasi hukum. Dalam menegakkan supremasi hukum tadi konstitusi merupakan mata air dan sekaligus muara penegakan negara hukum kesejahteraan yang demokratis.

\section{B. Sumbangan Pendidikan Hukum Konstitusi Terhadap Kehidupan Negara, Bangsa, dan Masyarakat}

Bahan-bahan belajar mengajar (pembelajaran) Hukum Konstitusi tersebut di atas merupakan konsep-konsep penting dalam memperkuat Pendidikan Kewarganegaraan mencapai tujuannya. Secara kesatuan pemahaman bahan-bahan belajar mengajar (pembelajaran) Hukum Konstitusi yang berintikan Pancasila dalam Pendidikan Kewarganegaraan tadi merupakan jantungnya pengembangan kehidupan suatu negara, bangsa, dan masyarakat madani (civil society).

Tanpa pemahaman atas konsep-konsep Hukum Konstitusi yang berintikan Pancasila dalam Pendidikan Kewarganegaraan tadi seorang warga negara sedikit banyak akan mengalami kesulitan menjadi warga negara yang baik, menjadi bagian dari karakter bangsa, menjadi bagian dari suatu bangsa, bagaimana cara menanamkan cinta tanah air dengan tepat, menjadikan dirinya bagian dari identitas nasional, bagaimana menjadi insan demokratis yang mendukung pemerintahan demokratis, bagaimana ia mengetahui kemakmuran perorangan mendukung kesejahteraan sosial, bagaimana menyadari pentingnya mencerdaskan diri dan memiliki keterampilan sosial sebagai bekal dalam mengarungi kehidupan dalam masyarakat suatu negara termasuk negara Indonesia.

\section{Penutup}

Dari uraian mengenai notifikasi Hukum Konstitusi melalui pendidikan dapat ditarik beberapa kesimpulan.

1. Hukum Konstitusi merupakan cabang hukum baru dari Hukum Tata Negara dalam arti luas. Dengan timbulnya cabang hukum 
baru ini, maka Hukum Tata Negara dalam arti luas terdiri atas tiga cabang hukum di dalamnya, yaitu: Hukum Konstitusi, Hukum Tata Negara dalam arti sempit, dan Hukum Tata Usaha Negara/Hukum Administrasi Negara.

2. Hukum Konstitusi dapat dipandang dari segi keilmuannya dan segi aturannya. Sebagai ilmu, Hukum Konstitusi adalah Hukum yang mempelajari konstitusi termasuk Undang-Undang Dasar sebagai dasar hukum tertulis tertinggi dari tata hukum nasional. Sebagai aturan, Hukum Konstitusi adalah seperangkat aturan dasar atau Hukum Dasar yang dibuat oleh yang berwenang yang menetapkan dan mengatur organisasi negara dari suatu negara.

3. Hukum Konstitusi mencakup Hukum Konstitusi dalam arti luas dan Hukum Konstitusi dalam arti sempit. Hukum Konstitusi dalam arti luas adalah Hukum Dasar, baik Hukum Dasar tertulis maupun Hukum Dasar tidak tertulis. Hukum Konstitusi dalam arti sempit adalah Hukum Dasar tertulis atau Undang-Undang Dasar atau Konstitusi.

4. Notifikasi Hukum Konstitusi adalah penyebarluasan pemahaman Hukum Dasar sebagai aturan-aturan dasar dalam penyelenggaraan negara, yang terdiri atas :

a. Notifikasi Hukum Dasar tertulis:

1. Notifikasi Hukum Dasar tertulis dalam arti luas meliputi Undang-Undang Dasar, Undang-Undang bermuatan konstitusi, Undang-Undang organik, Undang-Undang non organik, Peraturan Pemerintah Pengganti Undang-undang (Perpu), Peraturan Pemerintah, Peraturan Presiden, Peraturan Menteri, Peraturan Daerah, Peraturan Kepala Daerah, peraturan pelaksanaan, peraturan kebijakan, peraturan khusus, peraturan putusan pengadilan/hakim, dan peraturan traktat terutama dalam lapangan ketatanegaraan.

2. Notifikasi Hukum Dasar tertulis dalam arti sempit, yaitu Undang-Undang yang menjadi dasar dari segala hukum berupa Undang-Undang Dasar atau Konstitusi.

b. Notifikasi Hukum Dasar tidak tertulis meliputi peraturan kebiasaan, peraturan kesepahaman/kesepakatan, peraturan adat istiadat, dan peraturan konvensi terutama dalam lapangan ketatanegaraan. 


\section{Daftar Pustaka}

Anwar, Chaerul. Konstitusi dan Kelembagaan Negara, Jakarta: CV. Novindo Pustaka Mandiri, 1999.

Asshiddiqie, Jimly. Konstitusi \& Konstitutionalisme Indonesia, Cetakan Pertama, Jakarta: Sekretariat Jenderal dan Kepaniteraan Mahkamah Konstitusi RI, 2005.

Budiardjo, Miriam. Dasar-dasar Ilmu Politik, Cetakan VI (Diterbitkan pertama kali 1972, Cetakan I 1977), Jakarta: PT. Gramedia, 1981.

Departemen Pendidikan dan Kebudayaan RI, Kamus Besar Bahasa Indonesia, Edisi Kedua, Cetakan Ketiga, Jakarta: Balai Pustaka, 1994.

Dicey, Albert Venn, An Introduction to Study of The Law of The Constitution, Tenth Edition (First Edition 1885), London: English Language Book Society and Macmillan, 1952.

Echols, John M. dan Hassan Shadily. Kamus Inggris Indonesia, Jakarta: PT. Gramedia.

Godechot, Jacques, Les Constitutions de La France Depuis 1789, Paris: Garnier-Flammarion, 1982.

Harun, Djaenudin. "Kontribusi Kurikulum IKIP (UPI) 1993 dalam Menyongsong Kurikulum Berbasis Kompetensi Mata Pelajaran Kewarganegaraan di Persekolahan", Jurnal Pendidikan Universitas Pendidikan Indonesia (UPI) Mimbar Pendidikan, No. 2 Tahun XXV 2006.

Indra, H., Muhammad Ridhwan. Undang-Undang Dasar 1945 Sebagai Karya Manusia, Jakarta: Pustaka Sinar Harapan, 1990.

Kelsen, Hans. General Theory of Law and State, Translated by Assistant Professor of Philosophy in the University of Stockholm Anders Wedberg, Copyright 1945, Copyright Renewed 1973, New York: Russell \& Russell, 1973.

Kusumaatmadja, Mochtar. Fungsi Dan Perkembangan Hukum Dalam Pembangunan Nasional, Bandung: Binacipta, 1970.

Mahfud MD., Mohammad. Demokrasi dan Konstitusi Di Indonesia Studi Tentang Interaksi Politik dan Kehidupan Ketatanegaraan, Cetakan Kedua, Jakarta: PT. Rineka Cipta, 2000. 
Manan, Bagir. Pertumbuhan dan Perkembangan Konstitusi Suatu Negara, Bandung: CV. Mandar Maju, 1995.

, Teori dan Politik Konstitusi, Cetakan Kedua (Cetakan Pertama 2003), Yogyakarta: Fakultas Hukum UII Press, 2004.

Martosoewignjo, R. Sri Soemantri. Prosedur dan Sistem Perubahan Konstitusi, Cetakan IV (Cetakan I 1978), Bandung: PT. Alumni, 1987.

Murphy, Walter F. James E.Fleming, and Sotirios A.Barber. American Constitutional Interpretation, Second Edition, New York: The Foundation, Inc., 1995.

Prodjodikoro, R. Wirjono. Asas-asas Hukum Tata Negara Di Indonesia, Cetakan Ketiga (Cetakan Pertama 1970), Jakarta: PT. Dian Rakyat, 1977.

Riyanto, Astim. Teori Konstitusi, Cetakan Ketiga (Cetakan Pertama 1993), Bandung: Yapemdo, 2006.

, Filsafat Hukum, Cetakan Kedua (Cetakan Pertama 2003), Bandung: Yapemdo, 2007.

Sastrosoehardjo, Soehardjo. Konstitusi \& Demokrasi Beberapa Pemikiran Tentang Hukum, Semarang: Dahara Prize, 1991.

South-East Asian and Pacific Conference of Jurists, Bangkok, February, 1519, 1965, The Dynamic Aspects of the Rule of Law in the Modern Age, International Commission of Jurists, Bangkok, 1965.

Strong, C.F. Modern Political Constitutions An Introduction to the Comparative Study of their History and Existing Form, Fifth (Revised) Edition 1958, Second Impression (First Printed 1930), London: Sidgwick \& Jackson Limited, 1960.

Thaib, Dahlan. Jazim Hamidi, dan Ni'matul Huda, Teori Hukum dan Konstitusi, Jakarta: PT. Raja Grafindo Persada, 1999.

Wahjono, Padmo. Indonesia Negara Berdasarkan Atas Hukum, Jakarta: Ghalia Indonesia, 1983.

Wheare, Kenneth C. Modern Constitutions, Third Impression (First Published 1951), London, New York, Toronto: Oxford University Press, 1975.

Yamin, Muhammad. Naskah-Persiapan Undang-Undang Dasar 1945, Jakarta: Yayasan Prapantja, 1959. 


\section{Artikel}

Agustis, Mubiar. Dosen Program PGTK UPI, "Menggugat Eksistensi Sekolah Rumah", Harian Umum Pikiran Rakyat, Bandung, Rabu, 19 Desember 2007.

\section{Peraturan Perundang-undangan}

Indonesia, Undang-Undang Dasar Negara Republik Indonesia Tahun 1945, Lembaran Negara 1959 Nomor 75.

, Perubahan Pertama Undang-Undang Dasar Negara Republik Indonesia Tahun 1945, Ditetapkan oleh Majelis Permusyawaratan Rakyat RI tanggal 19 Oktober 1999.

, Perubahan Kedua Undang-Undang Dasar Negara Republik Indonesia Tahun 1945, Ditetapkan oleh Majelis Permusyawaratan Rakyat RI tanggal 18 Agustus 2000.

, Perubahan Ketiga Undang-Undang Dasar Negara Republik Indonesia Tahun 1945, Ditetapkan oleh Majelis Permusyawaratan Rakyat RI tanggal 9 November 2001.

, Perubahan Keempat Undang-Undang Dasar Negara Republik Indonesia Tahun 1945, Ditetapkan oleh Majelis Permusyawaratan Rakyat RI tanggal 10 Agustus 2002.

, Undang-Undang Republik Indonesia Nomor 10 Tahun 2004 tanggal 22 Juni 2004 tentang Pembentukan Peraturan Perundangundangan (Lembaran Negara 2004 Nomor 53, Tambahan Lembaran Negara Nomor 4389).

, Undang-Undang Republik Indonesia Nomor 32 Tahun 2004 tanggal 15 Oktober 2004 tentang Pemerintahan Daerah (Lembaran Negara 2004 Nomor 125, Tambahan Lembaran Negara Nomor 4437).

Departemen Pendidikan Nasional, Keputusan Direktur Jenderal Pendidikan Tinggi Departemen Pendidikan Nasional RI Nomor 43/Dikti/Kep/2006 tentang Rambu-rambu Pelaksanaan Kelompok Mata Kuliah Pengembangan Kepribadian Di Perguruan Tinggi. 